\title{
The relationship of Brand Commitment, Brand Credibility, Perceived Quality, Customer Satisfaction and brand loyalty: an empirical study on Stylo shoes
}

\author{
Muhammad Rizwan (Corresponding author) \\ Lecturer, Department of Management Sciences, \\ The Islamia University of Bahawalpur, Pakistan \\ E-mail: rizwan.arshad@iub.edu.pk
}

\author{
Pakeeza Anum Javed ${ }^{1}$, Javaria Aslam ${ }^{2}$, Rushmeen $\mathrm{Khan}^{3}$, Humaira Bibi ${ }^{4}$ \\ ${ }^{1,2,3,4}$ Department of Management Sciences, the Islamia University of Bahawalpur, Pakistan
}

Doi:10.5296/ jsr.v5i1.6572 URL: http://dx.doi.org/10.5296/ jsr.v5i1.6572

\begin{abstract}
Group advertisement can help build brands, but dependability is what makes them preceding. If people believe they share values with an organization, they will remain loyal to the particular brand." There is only one boss 'the customer' and he can fire everybody in the company, simply investing money somewhere else, he wants. Keeping in mind that costumers are a challenging aspect for organizations, our study aims to contribute in the brand loyalty. There is a rapid increase seen in the needs of brands in the market, now a day. Customers feel good, safe, proud, sophisticated, satisfied and obliged having brands, explained by research. As customers want brands and the main purpose of this research paper was to study the contribution of brand equity, perceived quality, consumer satisfaction, brand commitment, brand credibility, and brand trust for building brand loyalty. Also, present the role of brand loyalty on brand equity. Our study also explains that how can be the customers remain loyal with a brand and what they need in it and what will be the future of all this. A self-administered questionnaire was developed to collect data from randomly selected 200 female consumers of Stylo shoes in Pakistan. We constructed a structural model and tested it. The SPSS analysis was performed in order to check the fit of conceptual model presented. To evaluate the relationship between variables, correlation and regression analysis was also used. The findings of this study demonstrate that all the variables positively and significantly effects brand loyalty. Additionally, the relationship of brand loyalty and brand equity was also seen. This article and its findings have numerous limitations and give directions for future work.
\end{abstract}

Keywords: Brand Loyalty, Stylo shoes, Customer needs, Market, Pakistan 


\section{Introduction}

With the growing era of technology and globalization, worldwide competition between businesses and around World Wide Web, 'Brand' is becoming a favorite topic for discussion. Brands are creating reputation, name, and fame for a product or a company in the market, where they facilitates customers and satisfy their needs and wants. Brands, due to their great importance, are being used in International trade. For that level of importance of a brand, brand loyalty is also very important for businesses especially in the field of marketing.

It is very difficult to make customers loyal for a brand, and satisfy those customers with the particular brand and eventually building brand loyalty and to become a company that leads and flourishes in the field of trade and marketing. In addition, brand determines the value of the organization in the aggressive environment. 'Brand' we can say a symbol or a name for a recognition and fame. Brand can be a mean to create a good will and a well-known image on the minds of consumers and is entirely different from competitors. It provides the opportunity for companies to make a group of loyal customers and increase market share. Brand loyalty of customers is to show a repeatedly purchase behavior and create a positive word of mouth about the brand and recommend that brand to others. Customer preferences are formed by the importance and functions about the choice of the brand by customers so organizations must be more efficient and effective in order to survive in the market. Brand is also becoming a decision making content in purchasing.

Actually, brand choice has a priority in the decision making of customers. Thus, brand influences customer repeat purchase behavior and his loyalty for a brand. That loyalty can be a positive one to create a strong relation with the brand and a negative one resulting in changing the brand. There are so much brands in the market of one kind, and customers having a lot of alternatives and options that they switch their brands according to their needs and satisfaction and this made easy for them to adopt the best brand and switch to the best alternative but this has made brand loyalty formation difficult(Wood, 2004). As brand loyalty, formation is becoming that much difficult, as a result researchers are getting more interested in this topic. Studies cleared that we cannot say single brand loyalty, but there are different types within it.

First one is affective loyalty, in this type, customers are emotionally attached to the brand and they are not willing to buy other alternate brands and eventually have attitude towards repurchasing of the brand in future. Moreover, an attitudinal index of brand loyalty defines the statements of preference or intentions to behave and not actual purchase behavior.

As well as our study is concerned, we are mainly studying brand loyalty and the effects of brand trust, brand commitment, perceived quality, brand credibility and customer satisfaction towards brand loyalty and the relationship between brand equity and brand loyalty. In addition, there are relationships that we ought to discuss about are between perceived quality and brand credibility; brand credibility and brand commitment; perceived quality and customer satisfaction.

Brand equity is that, a brand provides a product with a value called as 'Added Value'. It has 
been and will be an area of interest for marketing managers. All marketing efforts are towards the development of brand equity. Therefore, researchers made efforts to understand the concept of brand equity as deep as possible. As companies own, a great asset that has a good deal of importance that is their brand, which can also be a competitive advantage for a company, easy to access and an extra hand for a company as compare to its competitors.

A brand has a great deal of importance in the market. As they build a relationship between the company and the consumers and consumers, show loyalty and trust towards a brand if they become satisfy with that. Experience about a brand is very important for a customer in taking decision about that particular brand to repurchase it or not. Most of the companies remain unsuccessful to implement the marketing mix, as the customers want to buy according to their requirements say on their own conditions. The companies are misunderstanding customers and their importance and along with that, they underestimate them by not fulfilling their requirements and making them unsatisfied. Additionally, companies are not giving perceived quality to the customers as they promises high about a product but performance of that product is low comparatively, this eventually lessens credibility of a brand, and thus loyalty is affected due to all these mishaps.

Brand loyalty is a most popular cognitive predictor of consumers' behavior toward a brand. The study of perceived quality and satisfaction along with loyalty created the service literature more important. Companies has a need to bind customers to their brands with full loyalty and this require customer's satisfaction most importantly, as the satisfied customers become loyal to that brand by showing their commitment.

\section{Literature review}

\subsection{What is brand loyalty?}

Brand is a "sign, expression, design, representation, or a name and can be a combination of all, representing a product (good or service) from a manufacturer or a manufacturing group that should be innovated and entirely different and unique from competitors of a company Kotler (1997)." Keller said that a product, an idea, service, a shop, a famous personality, place or an organization all could be a brand (2003). It is more than a name, logo or a good will. Davis said that collection of views and observations and experiences created by the recognition of a product is a brand (2002). Components of a brand, tangible or intangible, interacts the perception of the customer, and can create a place in the minds of customer with the passage of time by satisfying their needs and wants being a developed and established brand.

When customers recognize a brand and perceive it good that make brand trustworthy in the eyes of customers and a strong positive relation developed between them and value of the brand is also increased in the viewpoint of customers, that will create customers' repurchase behavior and thus loyalty is build. A customer chooses products based on brands, this creates the link between producers and customers, which enable customers to buy value and become satisfied. Brands also give repute to customers so they should consider brand while purchasing. Customer's awareness about a brand and its importance make a brand popular 
and creates loyalty towards it. An interesting thing has been seen that in a product its packaging, price and technical characteristics are more important than the brand to evaluate that product (Serge, 2000). Popular brands provide more value of a product than a less popular brand and they give full information about those values (Keller, 2003).

Organizations face various challenges in the market through competition, national and international trade, and technology and about customer satisfaction. These challenges make these organizations suffer a lot to improve their products and lessen the prices, which results a long-term relationship between customers and brand awareness by the customers. Those organizations, which attract customers well from the good performance of their brands, are more successful. This gives those organizations the opportunity to make their customers loyal. There are different levels of customer satisfaction, commitment and loyalty for a brand (a product or service) (kandampully and Sunartanto, 2000). Brand loyalty is to show a repurchase behavior for a brand and having a positive and good attitude towards it.

Liu said that a repurchase behavior of a customer for a brand and his or her commitment towards it to buy it in the future for a long time is brand loyalty (2007). Researchers and writers gave so many definitions of brand loyalty, so it is very difficult to find only one definition agreed by all. So here, we will take some definitions of brand loyalty given by different research scholars. Jacoby very firstly discussed brand loyalty and was awarded for that, he gave first definitions of loyalty and laid its foundation.

Brand loyalty is a long-term behavior of customers to buy only one brand in more alternatives (Jacoby and Chestnut, 1978). Brown (1952) studied that loyalty is to purchase the same brand over times repeatedly in all conditions. Jalab (1952) stated that Customer's choice to buy a specific brand is brand loyalty. In addition, Najem (1952) defined loyalty as to what extent customers buy a particular brand. Guest (1964) suggested that customer preferences are the only criteria to estimate loyalty. Oliver (1999) said that commitment of customers to repurchase a brand for a long time in the future is loyalty. In contrast, Cunningham (2000) defined loyalty as comparison between competitor brands that which one is purchased more frequently. In 2001, Mowen and Minor stated that a positive attitude towards the purchase of a brand and commitment to buy it repeatedly in the long run. Tawfeq (2007) said that the habits of repurchasing of customers evaluate loyalty. We can say that a customer purchases products from only one organization even if other organizations provide more incentives and shows better performance by products.

\subsection{Brand trust}

Scholars gave trust a great deal of importance and attention in various disciplines like sociology (Weigert and Lewis 1985), psychology (Huston and Larzelere 1980; Deutsch 1960; Rotter 1980; Rempel et al. 1985) and economics (Dasgupta 1988). Along with this attention, trust is also in many functional regions like marketing (Dwyer et al. 1987; Hunt and Morgan 1994; Andaleeb 1992) and management (Hausen and Barney 1994) Trust is being very important in building brand loyalty, explained from studies (Schefter \& Reicheld, 2000; Berry, 1995; Holbrook and Chaudhuri, 2001; Hunt \& Morgan 1994, Hollis, Dyson \& Farr, 1996). Scholars also showed the importance of trust in the field of marketing (Scherer, Dwyer 
\& Oh, 1987; Hunt \& Morgan, 1994; Andaleeb, 1992). There are many concepts of trust given by various scholars of different fields; here we mention some of their viewpoints. Deutsch (1973) Trust is the assurance about a product that it is not feared that requirements will be fulfilled (p. 148). Customer's belief that a brand would provide the best quality, which is being promised, and they can depend on that particular brand. While we define brand trust as what customers perceive about the value they acquire and cost incurred (Singh \& Agustin 2005). Hansen \& Barney (1994) studied that a mutual understanding that neither party will violate the rules of honesty against each other is trust.

Hunt \& Morgan said that a confidence in a trade in which two parties shows truthfulness and dependability on each other is trust (1994, p. 23). They show trust and other traits of accountability, sincerity, justice, cooperation and generosity. Brand loyalty maintains a good relationship that trust is creating (Cemal et.al, 2011). In other terms, trust builds relation with loyalty and their link is very important to study. Trust on a brand is build by its consistent good performance and sudden response that customers have that created their belief on that brand that their expectations are being fulfilled (Leonard \& Ashley 2009). Hunt \& Morgan (1994) and Moorman, et.al (1992) studied about the positive directive relation of brand trust and brand loyalty that is when brand trust increases loyalty of customers also increases. Therefore, studies showed that brand trust contributes not only in attitudinal loyalty but also in the purchase or behavioral loyalty.

\section{H1: Brand trust positively and significantly affects loyalty of a brand.}

\subsection{Customer Satisfaction}

In the marketing viewpoint there are number of definitions of satisfaction, over the years. Cote \& Giese studied one of the wide and varied definition of customer satisfaction and according to that an outline affective reaction of unstable intensity with a time-specific point of determination and inadequate period intended for essential points of brand acquirement and/utilization (2000, p. 15).

Satisfaction is the customer's evaluation about a product that to what extent that brand is meeting the wants and needs of the customers to their expected level. San Martin \& Rodriguez Del Bosque studied the two aspects of satisfaction that are motivative along with cognitive (2008). On the other hand, studies showed that there are numerous definitions of customer satisfaction, which varies from each other. We can measure satisfaction by two means; one is transaction- specific that shows customer satisfaction as a whole. This type of satisfaction is evaluated and judged suddenly by post-purchase and is the reaction of a customer that experienced recently a firm (Oliver, 1993).

Second one is transactional-specific, a post consumption and one time encounter with the firm creates satisfaction that can be with a particular employee you deal with (Suh \& Jones 2000). While according to (Bitner \& Hubert, 1994) it is the last purchase and all time encounters with the firm and judged all these. Consequently, satisfaction as a whole is the combination of all transaction- specifics among the encounters of service (Gilbert, Moutinho, Veloutsou) varied along with experience whereas satisfaction collectively is the 
attitude towards a brand and to purchase it (Johnson, Auh, Salisbury \&, 2003).

This whole concept is very important to measure satisfaction, which is a good scale to find loyalty and performance of a business in the future (Fornell, 2001). Thus, we can say that customer's responses emotionally towards the experience of a brand and his last purchase and that is satisfaction of a customer. According to the intellectual study, the difference between expectations and perception of a customer towards the purchase of a brand is customer satisfaction (Oliver, 1977; Surprenant \& Churchill 1982; Yi, 1990 and Tse \& Wilton in 1988). If performance of a brand is more than the expectation of a customer, then there will be a positive reaction of customer and customer would appraise and would be delighted.

A number of researchers studied that Antecedent of customer repurchase behavior and intention towards a brand and their attitude toward brand loyalty is satisfaction (Pritchard et al., 1999; Oliver, 1980; Russell- Bennett et al., 2007). Satisfaction increases loyalty when we measure brand loyalty in a number of Successive purchases of the same brand (LaBarbera and Mazursky, 1983). This proposed that customer satisfaction influences loyalty of a brand.

H2: Customer satisfaction is effectively, positively and significantly affects the loyalty of a brand.

\subsection{Perceived quality}

According to Anderson, 1993; Chen, 2001; Olsen, 2002 Scholars view perceived quality as special and biased. Oliver's (1999) definition of perceived quality is a worldwide buyer opinion of the supremacy of the product or service integrating consumer requirement and perceptions.

Perceived quality is the Consumer's judgment about a product's ability to fulfill his expectations. It may have somehow or nothing to do with the actual performance of the product, and is depends on the firm's (or brand's) current image (corporate image), customer's experience with the firm's all other products, It also based upon the result of the opinion leaders, consumer's peer group, and others. In order for a company's offer to reach the customers, there is a need for services/products. These products/services depend on the type of product and it differs in the various organizations. Quality is one of the important things consumer want to see in an offer, which service happens to be one. By Kotler et al., 2000 Quality is defined as the sum of features and characteristics of a product or services that stand on its ability to fulfill stated or implied expectation. Consume can develop brand love based on perceived quality and value thus finally develops brand loyalty.

Since the literature review is well describing the link of perceived quality and customer loyalty, there is a relatively limited relationship between perceived quality and brand loyalty. For example, the brand equity literature views two constructs as dimensions of brand equity (Aaker, 1996; Keller, 1998; Parasuraman and Grewal, 2000; Yoo et al., 2000), but relatively few studies have focused on the relationship between the two constructs (Chiang, 1991; McConnell, 1968). Such a relationship has the potential to contribute differentially to 
customer attitudes and behaviors, because the strength of brand loyalty could be Ha and Park 6747 explained by perceived quality (McConnell, 1968). Thus, we hypothesize the following:

\section{H3: Perceived quality has positive effect on brand loyalty.}

\subsection{Perceived quality and customer satisfaction}

Customer is king and management's first priority is to satisfy them because they are the major stakeholders in the organization. In addition, customer satisfaction has been an area under discussion of great importance to organizations and researchers. Now, organizations are welcome to provide more services in addition to their offers. Customer satisfaction is all about quality service delivery. Some researchers have proved the relation of service quality and customer satisfaction. The academic literatures propose that customer satisfaction is a function of the difference between a consumer's prior prospect and his or her sensitivity concerning the purchase (Churchill \& Surprenant, 1982; Tse \& Wilton, 1988; Oliver, 1977; Yi, 1990).

When a practice is better than the customer expected is, there is a positive disconfirmation of the expectation and a favorable customer evaluation. Previous research support predictive effect of perceived Quality on customer satisfaction. For example, Cronin and Taylor (1992) assess several models and conclude that satisfaction is a result of perceived quality. Lee and iBack (2008) also have the same opinion like Tylor. This link has also been previously established in numerous other quality Studies (Brady and Robertson, 2001; Fornell, 1992; Tse And Wilton, 1988). The link of perceived quality to Satisfaction is a good predictor of brand loyalty because consumer behavior Theory suggests that cognition (evaluation of service Quality) influences affect (judging the satisfaction for the Service) (Brady and Robertson in 2001).

\section{H4: Perceived quality has direct positive effect on customer satisfaction.}

\subsection{Brand Commitment}

According to Kiesler, (1971) the concept of commitment is, having intended aspects in psychology, and his definition of commitment: "the individual's pledging or obligatory behavioral acts". Commitment level is a psychological condition that globally represents the experience of dependence on a relationship, feelings of connection to a partner and a desire to maintain the relationship a long-term orientation towards it. Cunningham (1967) was one of a few early researchers viewing brand commitment as a predecessor of loyalty intentions.

Bloemer and Kasper (1995), Kim et.al, also took a similar view of commitment. (2008); Knox and Walker (2001); Mathew, Thomas and Khader (2011) and Verhoef (2003) Findings of Chaudhuri (1999) support this view that customers with commitment along with a sense of loyalty have enabled the brand to gain higher prices, positive word of mouth and lower advertising cost in the long run. Based on these arguments we propose the following 
hypotheses:

\section{H5: Brand commitment has a direct positive effect on brand loyalty.}

\subsection{Brand Credibility}

Brand credibility is a multi-characteristic term showing the integrity of the brand in the eyes of customers. Erdem and Swait (1998) define brand credibility as the brand having believability and reliability of product position information contained in a brand, in terms of reliability, claim-justification, and trust dispersion and delivering which entails consistently delivering what is promised. Stating clearly by Sternthal and Craig, 1982: Erdem and Swait 2004, brand credibility is a three-fold term necessitating dependability, aptitude and magnetism. Trustworthiness means that it is believable that a brand will deliver the promise thing, and aptitude implies that the brand is capable of delivering the promises and attractiveness means that apparently the brand is also fulfilling the promise it has made about its good appearance.

Brand's customer base and company's market share are affected by Brand credibility (Chaudhuri and Holbrook, 2001). Brand signaling theory also peeps into this significance by implying the relevance of brand credibility in fabricating brand equity (Swait and Erdem, 1998). Brand manufactures are firmly in search of motivators that can considerably agree, towards the intensification of brand credibility.

Having the belief that the brand warrants its publicized qualities can build up a strengthened and ongoing confidence between the manufacturer and its customers. Maathuis et al. (2004) and Swait and Erdem (2007) have insisted on the significance of brand credibility in consumer's decision-making and choice perceptions. Brand credibility refers to as risk-minimization approach for customers as they commend the brand qualifications and regarding the products worth they have convincing psychological motivation. It result in increasing the intrinsic risk, which customers see, but also reduces the information outlay while reaching a decision to use the product (Shugan, 1980) and thus increases brand loyalty. A credible brand leads towards higher levels of consumer loyalty.

H6: Brand credibility has a positive and significant relation with brand loyalty.

\subsection{Brand credibility and brand commitment}

A customer who perceives higher credibility with the offering stands to consider the efforts taken by firm for an interaction with him/her more favorably, leading to commitment with the brand (Ganasan 1994)

\section{H7: Brand credibility has a positive and significant effect on brand commitment.}




\subsection{Perceived quality and brand credibility}

A consumer's prejudiced assessment of the brand is referred to as the perceived quality of the brand (Zeithaml, 1988) improvement in the credibility of the brand in the eyes of the customers is because of higher quality perceptions related to a product. The relationship between perceived quality and brand credibility is that a credible brand may not have the best available quality among the available brands. Sometimes, a moderate-valued product may be more credible to customers due to the perception that they offer what they broadcast or spell out. Therefore, truthfulness in this regard may also yield higher brand reliability as compared to the competitors who are not consistent. Credibility linked with higher or lower perceived quality also affects the feeling of customers towards prices. Generally, consumers who

Highly-perceive a brand are less receptive to prices as compared to those perceiving brands of lower excellence (Krishnamurthi et al., 1992). Thus, they perceive the promised greater quality that increased their trust and believability on brand.

\section{H8: Perceived quality positively affects brand credibility.}

\subsection{Brand equity}

There are two wide approaches in defining brand equity, the first approach from firm perspective and other from customer. Brand equity outcomes are the basis of first approach such as price and market share while the second approach has attitudinal relations (Chaudhuri 1999). Accordingly, there are different definitions for brand equity (Aaker 1991, 1996; Keller 1993). Aaker (1991) defined brand equity as "A set of brand assets and liabilities referred to a brand, its name and symbol that add to or subtract from the value to their customers, provided by a product or a service of a firm". Keller (1993) defined, Consumer based brand equity (CBBE) as "the discrepancy effect that the brand awareness has on customer responses to the marketing of a definite brand. Study shows ten measures of brand equity under five categories as measures in loyalty, perceived quality, relations and responsiveness, all taken straightforwardly from customers; and a set of market performance (market share and price and distribution indices) measures which are derived from the market place (Aaker 1996).

Brand is that which has positive customer based brand equity when customers prefer to a marketed product and the method when the brand is recognized, as compare to when it is not." For building a strong brand, this model, estimated four most significant steps acquired for namely brand meaning are estimated, brand associations, brand uniqueness and brand responses. He also proposed that there are six building block of brand building - salience, performance, metaphors, judgments, feelings, and quality. Keller also emphasized the order to place these building blocks.

Brand equity has alternating definitions and these alternate definitions show a discrepancy much (Ha, Janda, \& Muthaly 2010; Rangaswamy, Bruke, \& Oliva 1993). Those definitions have some combinations of consciousness, partiality and loyalty. Kartono and Rao (2005) pointed out that there may not be a common method of creating an exhaustive list of 
formative indicators for brand equity for all brands, while Aaker (1996); Erdem and Swait (1998) pointed the need of a customized approach.

In addition, research conducted by Chaudhuri (1999) has found that brand loyalty has a positive effect on brand equity Findings by Atilgan et.al. (2005): Joseph and Sivakumaran (2009) supported the view that loyalty significantly affects the brand equity. Thus, we propose the following hypothesis:

\section{H9: Brand loyalty has a direct positive effect on brand equity.}

\section{Research Methodology}

We are using descriptive type of research. Moreover, Descriptive research refers to as explaining something, some observable fact of any exacting situation. These researches do not interpret or make decisions but describe the existing situation (Creswell. 1994). The main aim of the descriptive research is to reflect the current situation by confirmation of the developed hypothesis. If we want to get information about current picture, descriptive research will be helpful it also focus on past and present for example excellence of life in a society or customer attitudes towards any promotion activity (Kumar, 2005).

\subsection{Sample/Data}

In order to collect the data for understanding the situation about customer's loyalty towards Stylo shoes, a sample of 200 respondents were asked to participate in self-administered questionnaire. The population for current research is the users of Stylo shoes in Pakistan.

The current study utilizes a non- probability sampling technique which is also called as convenience sampling. A technique that obtains and collects relevant information from sample or from a unit of study that are conveniently available is convenience sampling (Zikmund, 1997). Convenience sampling is normally used for reducing cost and increasing efficiency. (Lym et al, 2010).

It has ensured that the sample members should have two main requirements to contribute in the self-administered study. Firstly, the sample members should be Stylo shoes users and having enough know how about Stylo shoes. Second, they never purchased any item over the Stylo shoes because in the case of experience regarding the purchase of Stylo shoes, it absolutely influences the approach and behavior of the respondent.

We choose these samples members from different metropolitan cities of Pakistan. Three main clusters will aim to collect the sample data like university students, housewives and working professionals, all are females. The selection of students, housewives and working professionals are based on the preceding results of the studies on brand loyalty. According to Wood (2002), young adults are more interested to buy Stylo shoes as comparatively others. Stated by Hubona and Kennick (1996) young community can easily be trained for the skills required to be loyal for a brand. For the repurchase behavior and become loyal of Stylo shoes income is also a factor to be considered (Shin, 2009). 


\subsection{Instrument and Measures}

The survey instrument of the current study address two major purposes: First is to analyze the relationship of different variables in consumer brand loyalty towards Stylo shoes. Second is to collect information about the different characteristics of the respondents that can be used to understand the variations in diversified groups. This study mechanism contains two sections. Section 1 contains different personal and demographic variables and this will obtain the personal information about the respondent like gender, age, income, education and status, frequency of purchase of Stylo shoes and possible future purchase of the product. Second section comprises upon latent variables that are important in current study. These variables are brand trust, brand commitment, perceived quality, brand credibility, customer satisfaction and brand equity and brand loyalty. Past literature and already used questioners is the base of this section of study (Table 1).

Scales of the study were adopted from the previous literature and published paper. The first two variable of the study were perceived quality and brand equity. They have four and three items respectively and their scales were taken from (Yoo et al, 2000). The third variable of the study is brand loyalty it has five items and its scales were taken from Chaudhuri and Holbrook, (2001), Yoo and Donthu (2001). The fourth variable of the study was brand trust it has five items and its scales were taken from Matzler it all, (2008) Chanduhuri and Holbrook, (2001). Next one is customer satisfaction, it has two items, and its scales were taken from Ragunathan and Irwin (2001). The sixth variable of the study is brand credibility, it has five items, and its scales were taken from Erdem and Swait (2004). The last variable of the study is brand commitment and it has five items and its scales were taken from the research paper Employees dedication to brands in service sector: Luxury hotel chains in Thailand'.

Table 1: Scale of the study

\begin{tabular}{|c|c|c|c|}
\hline No. & Variable & Items & Reference \\
\hline 1 & Brand Loyalty & $\begin{array}{l}\text { 1. This brand (Stylo shoes) would be } \\
\text { my first choice. } \\
\text { 2. I consider myself loyal to this } \\
\text { brand. } \\
\text { 3. I will not buy any other brand if } \\
\text { the same product is available at } \\
\text { the store. } \\
\text { 4. I recommend this brand to } \\
\text { someone who seeks my advice. } \\
\text { 5. I get good value for my money. }\end{array}$ & $\begin{array}{l}\text { (Chaudhuri and } \\
\text { Holbrook, 2001) }\end{array}$ \\
\hline
\end{tabular}




\begin{tabular}{|c|c|c|c|}
\hline 2 & Brand Trust & $\begin{array}{l}\text { 1. I trust on this brand (Stylo shoes). } \\
\text { 2. I rely on this brand. } \\
\text { 3. This is an honest brand. } \\
\text { 4. This brand meets my } \\
\text { expectations. } \\
\text { 5. This brand is safe. }\end{array}$ & $\begin{array}{l}\text { Matzler it al, (2008) } \\
\text { Chanduhuri and } \\
\text { Holbrook,(2001) }\end{array}$ \\
\hline 3 & $\begin{array}{l}\text { Brand } \\
\text { Commitment }\end{array}$ & $\begin{array}{l}\text { 1. I usually tell my friends that this } \\
\text { is a great brand (Stylo shoes) to } \\
\text { buy. } \\
\text { 2. I am proud to tell others that I use } \\
\text { this brand. } \\
\text { 3. For me this is the best of all } \\
\text { possible brands I used. } \\
\text { 4. I am extremely glad that I choose } \\
\text { this brand over others I was } \\
\text { considering. } \\
\text { 5. I really care about this brand. }\end{array}$ & $\begin{array}{l}\text { 'Employees' } \\
\text { commitment to brands } \\
\text { in the service sector: } \\
\text { Luxury hotel chains in } \\
\text { Thailand' }\end{array}$ \\
\hline 4 & $\begin{array}{l}\text { Perceived } \\
\text { Quality }\end{array}$ & $\begin{array}{l}\text { 1. This brand (Stylo shoes) is of high } \\
\text { quality. } \\
\text { 2. It is likely that the brand is of very } \\
\text { high quality. } \\
\text { 3. It is likely that brand is of very } \\
\text { consistent quality. } \\
\text { 4. It is likely that the brand offer } \\
\text { excellent features. }\end{array}$ & Yoo et al (2000) \\
\hline 5 & $\begin{array}{l}\text { Brand } \\
\text { Credibility }\end{array}$ & $\begin{array}{l}\text { 1. This brand (Stylo shoes) has the } \\
\text { ability to deliver what it promises. } \\
\text { 2. This brand delivers what it } \\
\text { promises. } \\
\text { 3. This brand's product claims are } \\
\text { believable. } \\
\text { 4. This brand has a name you can }\end{array}$ & $\begin{array}{l}\text { Erdem and Swait } \\
(2004)\end{array}$ \\
\hline
\end{tabular}




\begin{tabular}{|c|c|c|c|}
\hline & & $\begin{array}{l}\text { trust. } \\
\text { 5. This brand does not pretend to be } \\
\text { something it is not. }\end{array}$ & \\
\hline 6 & $\begin{array}{l}\text { Customer } \\
\text { Satisfaction }\end{array}$ & $\begin{array}{l}\text { 1. Overall, I am satisfied with } \\
\text { specific experience with the brand } \\
\text { (Stylo shoes). } \\
\text { 2. I am satisfied with my decision to } \\
\text { purchase from this brand. }\end{array}$ & $\begin{array}{l}\text { Ragunathan } \\
\text { Irwin(2001) }\end{array}$ \\
\hline 7 & Brand Equity & $\begin{array}{l}\text { 1. It makes sense to buy Stylo shoes } \\
\text { instead of any other brand even if } \\
\text { another brand has the same, } \\
\text { features as Stylo shoes. } \\
\text { 2. There was another brand as good } \\
\text { as Stylo shoes. } \\
\text { 3. Another brand is not different } \\
\text { from Stylo shoes in any way. }\end{array}$ & Yoo et al. (2000) \\
\hline
\end{tabular}

\subsection{Procedure}

The 200 respondents in Bahawalpur and sadiqabad filled the questionnaire. The respondents' selection criteria have been mentioned above. For respondents' easiness, the purpose of study and questions were explained for easy fill up and relevant responses. Only 151 questionnaires were used for analysis because rest of the questionnaire responses was invalid and incomplete. SPSS sheet were used to enter and code data. Regression analysis was also used for further processing.

\subsection{Reliability Analysis}

According to Nanually (1970) and Moss et al. (1998), 0.50 and 0.60 value of Cranbach's alpha of all the variables on brand loyalty towards Stylo shoes is more than the satisfactory and suggested value. It indicates that all 29 items were consistent, applicable, and helpful in measuring opinions of consumers towards brand loyalty of stylo shoes. 
Table 2: Reliability of Measurement mechanism

\begin{tabular}{|l|l|l|}
\hline Scales & Items & Cronbach Alpha \\
\hline Brand Loyalty & 5 & 0.889 \\
Brand Trust & 5 & 0.890 \\
Brand Commitment & 5 & 0.910 \\
Perceived Quality & 4 & 0.886 \\
Brand Credibility & 5 & 0.890 \\
Customer Satisfaction & 2 & 0.887 \\
Brand Equity & 3 & 0.663 \\
\hline
\end{tabular}

\section{Results and Analysis}

\section{Profile of the Respondents}

Personal data and demographics such as age, income, educational level, status, frequency of instrument used potential purchase over the Stylo shoes are presented in the following (table $3)$.

Table 3: Profile of the Respondents

\begin{tabular}{|l|l|l|l|}
\hline Variable & Category & Frequency & Percentage \\
\hline Age & $\begin{array}{l}\text { 15-20Years } \\
20-25 \text { Years }\end{array}$ & 54 & 35.8 \\
$25-30$ Years & 5 & 48.3 \\
$30-35$ Years & 7 & 3.3 \\
$35-40$ Years & 10 & 4.7 \\
Above 40 Years & 2 & 6.6 \\
Income (Rs/Month) & Below 15000 & 109 & 1.3 \\
\hline $15000-25000$ & 22 & 72.2 \\
$25000-35000$ & 10 & 6.6 \\
\hline
\end{tabular}




\begin{tabular}{|c|c|c|c|}
\hline & $\begin{array}{l}35000-45000 \\
45000-55000 \\
\text { Above } 50000\end{array}$ & $\begin{array}{l}7 \\
2 \\
1\end{array}$ & $\begin{array}{l}4.6 \\
1.3 \\
0.7\end{array}$ \\
\hline Education & $\begin{array}{l}\text { Matriculation } \\
\text { Inter } \\
\text { Bachelor } \\
\text { Master } \\
\text { MS/M. Phil } \\
\text { PHD }\end{array}$ & $\begin{array}{l}10 \\
15 \\
79 \\
29 \\
18 \\
-\end{array}$ & $\begin{array}{l}6.6 \\
9.9 \\
52.3 \\
19.2 \\
12 \\
-\end{array}$ \\
\hline Status & $\begin{array}{l}\text { Students } \\
\text { Employed } \\
\text { Unemployed } \\
\text { Businesswomen } \\
\text { Housewife }\end{array}$ & $\begin{array}{l}111 \\
18 \\
5 \\
4 \\
13\end{array}$ & $\begin{array}{l}73.5 \\
11.9 \\
3.3 \\
2.7 \\
8.6\end{array}$ \\
\hline
\end{tabular}

\section{Hypothesis Testing}

\subsection{Brand loyalty and Brand trust}

The results of the study show brand trust has a significant positive relation with brand loyalty towards Stylo shoes. Specifically, brand trust has a significant positive relation with $(\beta=0.110)$ and $(\mathrm{p}<0.05)$ to brand loyalty. That means brand trust contribute $11 \%$ to brand loyalty of Stylo shoes. Results of the current study validate $\mathrm{H} 1$.

\subsection{Brand loyalty and customer satisfaction}

The results of the study confirms that there is a significant positive relationship between brand loyalty and customer satisfaction $(\beta=0.147)$ and $(p<0.05)$. The results prove that customer satisfaction contributes more than $14 \%$ to brand loyalty. These results of the study validate $\mathrm{H} 2$.

\subsection{Brand loyalty and perceived quality}

The analysis of the brand loyalty model shows that there is a positive significant relationship 


\section{Macrothink}

between brand loyalty and perceived quality with $(\beta=0.143)$ and $(p<0.05)$. The results describe that perceived quality contribute more than $14 \%$ to brand loyalty. The result of the study validates $\mathrm{H} 3$.

\subsection{Customer satisfaction and Perceived quality}

According to the results of the study, customer satisfaction has a significant positive relation with perceived quality towards Stylo shoes. Specifically, perceived quality has a significant positive relation with $(\beta=0.698)$ and $(p<0.001)$ to customer satisfaction. That means perceived quality contribute $11 \%$ to customer satisfaction of Stylo shoes. Results of the current study validate $\mathrm{H} 4$.

\subsection{Brand loyalty and brand commitment}

The results of the study confirms that there is significant positive relation between brand loyalty and brand commitment $(\beta=0.425)$ and $(p<0.001)$. According to these results, brand commitment contributes more than $42 \%$ to brand loyalty. These results of the study validate H5.

\subsection{Brand loyalty and brand credibility}

The analysis of the brand loyalty model shows that there is a positive significant relationship between brand loyalty and brand credibility with $(\beta=0.247)$ and $(p<0.01)$. The results suggest that brand loyalty contribute more than $24 \%$ to brand loyalty. The result of the study validates H6.

\subsection{Brand commitment and brand credibility}

The results of the study confirms that there is significant positive relation between brand commitment and brand credibility $(\beta=0.770)$ and $(p<0.001)$. According to these results, brand credibility contributes $77 \%$ to brand commitment. These results of the study validate $\mathrm{H} 7$.

\subsection{Brand credibility and perceived quality}

The analysis of the brand loyalty model shows that there is a positive significant relationship between brand credibility and perceived quality with $(\beta=0.743)$ and $(p<0.001)$. The results suggest that perceived quality contribute more than $74 \%$ to brand credibility. The result of the study validates $\mathrm{H} 8$.

\subsection{Brand equity and brand loyalty}

The analysis of the brand loyalty model shows that there is a positive significant relationship between brand equity and brand loyalty with $(\beta=0.534)$ and $(p<0.001)$. The results suggest 
that perceived quality contribute more than $74 \%$ to brand credibility. The result of the study validates $\mathrm{H} 9$.

Table four shows the collective results of the regression analysis of the study and Figure 2 shows the graphical representation of the structural model of our study.

Table 4 regression results

\begin{tabular}{|c|c|c|c|c|c|c|c|}
\hline Hypothesis & Model Variables & & Estimate & S.E & C.R & $\mathbf{P}$ & Results \\
\hline H1 & $\begin{array}{l}\text { Brand Loyalty } \\
\text { Trust }\end{array}$ & Brand & 0.110 & 0.089 & 1.821 & 0.018 & Supported \\
\hline $\mathrm{H} 2$ & $\begin{array}{l}\text { B.L } \\
\text { Satisfaction }\end{array}$ & Customer & 0.147 & 0.055 & 2.741 & 0.015 & Supported \\
\hline H3 & $\begin{array}{l}\text { B.L } \\
\text { Quality }\end{array}$ & Perceived & 0.143 & 0.077 & 1.918 & 0.040 & Supported \\
\hline $\mathrm{H} 4$ & C.S $\longleftarrow$ P. & & 0.698 & 0.071 & 11.891 & $* * *$ & Supported \\
\hline H5 & $\begin{array}{l}\text { B.L } \longleftarrow \\
\text { Commitment }\end{array}$ & Brand & 0.425 & 0.066 & 6.136 & $* * *$ & Supported \\
\hline H6 & $\begin{array}{l}\text { B.L } \\
\text { Credibility }\end{array}$ & Brand & 0.247 & 0.076 & 3.355 & 0.001 & Supported \\
\hline H7 & $\begin{array}{l}\text { B. } \mathrm{C} \\
\text { Credibility }\end{array}$ & Brand & 0.770 & 0.056 & 14.739 & $* * *$ & Supported \\
\hline $\mathrm{H} 8$ & Brand Credibility & P.Q & 0.743 & 0.055 & 13.536 & $* * *$ & Supported \\
\hline H9 & $\begin{array}{l}\text { Brand } \\
\text { B.L }\end{array}$ & Equity & 0.534 & 0.059 & 7.719 & $* * *$ & Supported \\
\hline
\end{tabular}


Figure 2: Structural Model Results

Figure 2: Structural Model Results

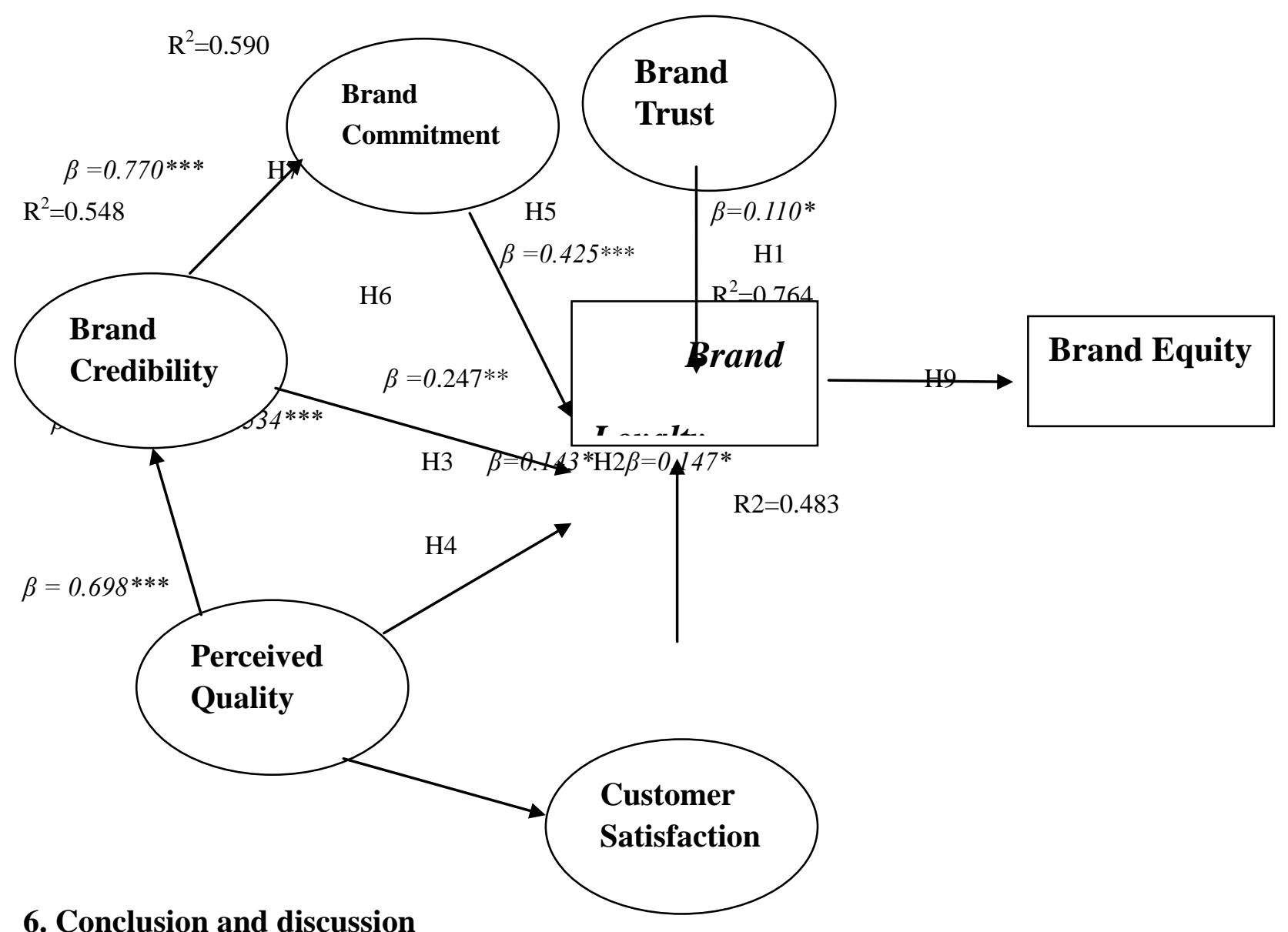

This paper has suggested what is practical, possible, and can be done by marketers in terms of brand equity, brand credibility, customer satisfaction, brand commitment, perceived quality, brand trust and brand loyalty. This research has provided information about female customer buying behavior. Marketers agree that developing an understanding of segments and target customers are important inputs in differentiating products and enhancing sales level. Brand loyalty makes sure that the products of that company are being kept in the minds of customers and prevents them to switch to another brand. The research results proves that, it was not easy to sustain and attain customer loyalty for a company's products because there were many forces drawing consumers away for example consumers' thirst for variety products, competitors etc. We found support in all hypotheses in our proposed model overall.

Statistical analysis result shows that trust in a brand is important and plays a key role in the development of brand loyalty. The effect of brand trust on brand loyalty was found supportive H1.Trust enhances loyalty, a study confirms the paths by which manufacturers build consumer trust and confirms a path from consumer trust to loyalty in relationship connections. 


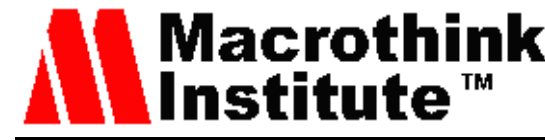

Through the creation of a highly valued exchange relation brand trust could achieve brand loyalty and to make consumers have the depth of commitment to the brand and to share some information about his or her choices, priorities, and behavior and this is the role of a factor that motivates. Brand can be trusted when it can fulfill customers' needs and expectation from the product; brands must build customer trust to improve their brand image in market. Management needs to ensure that the brand product acquired by the customers is what is expected in order for the brand image to be believable and for brand trust to be established.

Moreover, this study enhances the existing knowledge by examining the effect of customer satisfaction on brand loyalty. This empirical study tries to inspect the level of customer satisfaction on the brand loyalty in the shoe industry. The relationship between customer satisfaction and brand loyalty has been well researched in customer markets. In such cases, as level of customer satisfaction increases with service quality the level of brand loyalty is also increased. The main effect of perceived quality on satisfaction would come as no wonder to researchers. The current judgment indicates that, the link of perceived quality to satisfaction performed the best in predicting the brand loyalty.

When the effect of brand commitment on brand loyalty and repurchase intentions was measured, it was found out that affective commitment with the specific brand had an important effect on repurchase intentions and brand loyalty, customers show a stronger emotional promise to their brand and they do not move to the other brand easily (Fullerton, 2003). The results obtained shows that, the commitment contributes more in the creation of customer loyalty. From this viewpoint of, businesses/organizations should attach more importance to affective commitment and creating trust for their brands. In order to be successful, businesses/organizations should offer valid and no of reasons to their customers to be always connected with their brand and make them buy their products and services by getting into the world of customers market. In this way, they can have best loyal customers.

Brand credibility has a significant positive relation with customer loyalty to specific brand. Perceived quality yields strong correlation coefficient with brand credibility. A brand may or may not be the best among the brands available there but it is considered that quality may bring more market share than other high-quality alternates may bring. Because of this reason brand manager should refrain from claiming things that the product misses and present a true picture of the specifications of the product. The study has examine how credibility improves the formation of brand commitment toward the specific brand, creates loyalty intentions in turn, leading to brand equity. This research finds that brand loyalty and brand credibility positively affect the brand equity and brand commitment consequently. These findings suggest the marketers to develop strategies for the enhancement brand equity among its customers.

\section{Recommendations}

Recommendations that are offered for those researchers who are interested in the related field and want to conduct subsequent studies: 


\section{Change the brands of the research}

New researchers can select several brands of shoes for evaluation and explore differences among varying brand personalities.

\section{Research variables Change}

Researchers can change variables in the study as there is a penalty of variables to develop brand loyalty in customers and each variable has its own exposure. In addition, the correlation among various variables is low in accordance with our study, it illustrates that there are other variables also which can be studied. Thus, the researchers working on the follow-up research must review other literature to choose different variables, measurement, dimensions and provide a more integrated survey.

\section{In new research, change the industry}

This is only an experimental analysis of our study, in the shoes industry, but the researchers working on the follow-up research can apply the same model to other industries for more verification of the results, so the model can be enthusiastically adapted to other applications.

\section{Native language}

Number of respondents faced problems with understanding of language such as English is not the native language of this country (Pakistan). Use of different alternate words or rephrasing the questions may find the solution of the issue. In addition, the questionnaire in the native language may solve the problem. Possibly additional items are designed in further studies in order to find the religious orientation of the respondents.

\section{Limitation and Future Research}

Even though this research contributes to the existing brand management reporting, it has some kind of boundaries also. First, one is that it is specific to only two cities (Bahawalpur, Sadiqabad) and only one brand (Stylo shoes). Second limitation relates to the size of the sample. The third limitation is that questionnaire research was targeted to mainly students. On the behalf of this information, study cannot be generalized to the whole population and to make possible the development of the external validity of the study, other service dominant brands model should be applied to the brand loyalty.

Even if, this research provides some preliminary insights into the relationships between brand loyalty, brand equity, brand credibility, customer satisfaction, brand trust, brand commitment, and perceived quality future research should build upon this research model and provide further information about the nature of these relationships in different circumstances.

This research finds that there is a strong relation between customer satisfaction and brand equity, brand loyalty, brand credibility, brand commitment, brand trust, and perceived quality. The most important limitation in this research is that it defines only one product category, which actually limits other fields to be universal. These results must be changed with diverse products and brand categories. 
Moreover, this study does not examine personal factors, and brand personality and brand involvement. We still need the progress of a more wide-ranging understanding of the relationship among brand loyalty, brand equity, and other relationship marketing related variables such as brand trust and brand experience. Brakus et al, said in 2009 that brand experience concept and scale development is very significant for further understanding and managing brand trust and brand loyalty concepts.

The research was limited by age, gender, and geographic location. Of course, additional studies are needed in order to identify the brand loyal customers. Other variables such as the amount of involvement, the perceived risk, the amount of time and so on are needed to profile brand loyal customers.

Moreover, additional measurements about brand personality, service quality, and brand communication should be technologically advanced, that may lead to the better explanation of brand and loyal customer relation outcomes. In 2001, Chaudhuri and Holbrook stated that in spite of the standers of the concept, brand loyalty dimension has not flourished in the marketing literature respective.

\section{References}

1. Aaker, D. A. (1991) Managing brand equity: Capitalizing on the value of a brand name New York: Free Press.

2. Aaker, D.A. (1996), Building Strong Brand, Free Press, New York, NY

3. Agustin, Clara and Singh Jagdip (2005) "Curvilinear Effects of Consumer Loyalty Determinants in Relational Exchanges", Journal of Marketing Research, XIII

4. Andaleeb, S. S. (1992) the trust concept: Research issues for channels of distribution", Research in Marketing, Vol.11, No.1, pp.1-34.International Research Journal of Finance and Economics - Issue 85 (2012) 122

5. Anderson and Sullivan, M.W. (1993), "The antecedents and consequences of customer satisfaction for firms"”, Marketing Science, Vol. 2 No. 2, pp. 125-43

6. Ashley, Christy and Leonard, Hillary A. (2009) "Betrayed by the Buzz? Covert Content and Consumer-Brand Relationships", Journal of Public Policy and Marketing, Vol.28, No.2, pp.212-220

7. Atilgan, E., Safak, A. \& Serkan, A. (2005) Determinants of brand equity: a verification approach in the beverage industry in Turkey Marketing Intelligence

8. Auh, S., Salisbury, L. C., \& Johnson, M. (2003) Order effects in customer satisfaction modeling Journal of Marketing Management, 19(3/4), 379-400

9. Barney, J. B. \& Hansen, M. H. (1994) "Trustworthiness as a source of competitive advantage",

10. Berry, L. L. (1995) "Relationship marketing of services growing interest, emerging perspectives", Journal of the Academy of Marketing Science, Vol.23, No.4, 
pp.236-245

11. Bitner, M. J., \& Hubbert, A. R. (1994) Encounter satisfaction versus overall satisfaction versus quality In R. T. Rust \& R. L

12. Bloemer, J.M. and Kasper, H.D.P. (1995), "The complex relationship between customer satisfaction and brand loyalty", Journal of Economic Psychology, Vol. 16 No. 2, pp. 311-29

13. Brady \& MK, Robertson CJ (2001) Searching for a consensus on the antecedent role of service quality and satisfaction: An exploratory cross-national study J. Bus Res., 51: $53-60$

14. Brakus, J. J., Schmitt, B. H., \& Zarantonello, L. (2009) Brand experience: What is it? How is it measured? Does it affect loyalty? Journal of Marketing, 73, 52-68.

15. Brown, G.H, 1952 Brand Loyalty: Fact or Fiction?, Acil erlisi? ZgAge 23, June 19, 53-55; June 30, 45-47; July 14. 54-56; July 28. 46-48; August 11. 56-58; September 1. 76-79

16. Cemal, Z, Azize S, Hakan K., Mehtap Ö. (2011) "The Effects of Brand Communication and Service Quality In Building Brand Loyalty Through Brand Trust; The Empirical Research On Global Brands", Procedia Social and Behavioral Sciences, Vol.24,pp. 1218-1231

17. Chaudhuri Holbrook MB (2001). The chain of effects from brand trust and brand affect to brand performance the role of brand loyalty. J. Mar. 65(2): 81-93

18. Chaudhuri, A., (1999), "The Relationship of Brand Attitudes and Brand Performance: the Role of Brand Loyalty”, Journal of Marketing Management, Vol. 9, No. 3, pp. 1-9.

19. Chen, S.L. (2001) the Relationship between Customer Loyalty and Customer Satisfaction, International Journal of Contemporary Hospitality Management, (May), 213-17 C Markaya, Dergisi, C, VI, and S: 1-2, S: 118.

20. Chiang J (1991). A simultaneous approach to the weather, what and how much to buy questions Mar. Sci., 10(4): 297-315

21. Churchill, G. A. J., \& Surprenant, C. (1982) an investigation into the determinants of consumer satisfaction Journal of Marketing Research, 19(4), 491-504

22. Creswell, J.W. (1994) Research Design: Qualitative \& Quantitative Approaches London

23. Cronin, J. and Taylor, S. (1992) "Measuring service quality: a re-examination and extension”, Journal of Marketing, Vol. 56, No.3, pp. 55-68

24. Cunningham, P. (2000) "Revisiting small business", Best's Rev., Vol.101, No.6, p.118

25. Cunningham, S.M., (1967), "Perceived Risk and Brand Loyalty", In: Donald F. Cox, ed., Risk Taking and Information Handling in Consumer Behavior, Boston: Harvard 
University Press, pp. 507-523.

26. Dasgupta, P. (1988)"Trust as a Commodity", in Trust: Making and Breaking Cooperative Relations, Ed Diego Gambetta, New York: Basil Blackwell, pp.49-72

27. Davis, S. (2002) "Implementing your BAM2 strategy: 11 steps to making your brand a more valuable business asset", Journal of Consumer Marketing, Vol.19, No.6, pp.503-513.

28. Deutsch, M. (1960) the Effect of Motivational Orientation upon Trust and Suspicion Human Relations, 13, 123-139. (1973), the Resolution of Conflict: Constructive and Destructive Processes, New n Haven CN: Yale University Press

29. Deutsch, M. (1973) The Resolution of conflict: Constructive and destructive processes, New Haven, CN, and Yale University Press

30. Dwyer, F. R., Schurr, P.H. \& Oh, S. (1987) "Developing buyer-seller relationship", Journal of Marketing, Vol.51, No.2, pp.11-27

31. Dyson, P., Farr, A. and Hollis, N.S. (1996), "Understanding measuring, and using brand equity”, Journal of Advertising Research, Vol. 36 No. 6, pp. 9-22

32. Employees commitment to brands in the service sector: Luxury hotel chains in Thailand' Journal of Brand Management (2009) 16, 532 - 544 Doi 10.1057/palgrave.bm.2550140: published online 5 December 2008, Received (in revised form): 21 November 2007

33. Erdem, T. and Swait, J. (1998), "Brand equity as a signaling phenomenon”, Journal of Consumer Psychology, Vol. 7 No. 2, pp. 131-57

34. Erdem, T. and Swait, J. (2004), "Brand credibility, brand consideration and choice", Journal of Consumer Research, Vol. 31 No. 1, pp. 191-9

35. Fornell, C. (1992) a national customer satisfaction barometer: The Swedish experience. Journal of Marketing, 56(1), 1-18

36. Fornell, C., Johnson, M. D., Anderson, E. W., Cha, J., \& Bryant, B. E. (1996). The American customer satisfaction index: Nature, purpose, and findings Journal of Marketing, 60(4), 7-18

37. Fullerton, G. (2003) when does commitment lead to loyalty? Journal of Service Research, 5(4), 333-344

38. Ganasan, S., (1994), "Determinants of Long-Term in Buyer-Seller Relationships", Journal of Marketing, Vol. 58, pp. 1-19

39. Giese, Joan, and Joseph Cote (2000), "Defining Consumer Satisfaction," Academy of Marketing Science Review, 2000 (1), 1-26

40. Guest, L. (1964) "A Study of Brand Loyalty", Journal of Applied Psychology, Vol.28, pp. 16-27 


\section{Macrothink}

Journal of Sociological Research

ISSN 1948-5468

2014, Vol. 5, No. 1

41. Ha and Park 6747 Effects of perceived quality and satisfaction on brand loyalty in China: The moderating effect of customer orientation African Journal of Business Management Vol.6 (22), pp. 6745-6753, 6 June 2012

42. Ha H Janda S, Muthaly S. (2010) Development of brand equity: evaluation of four alternative models The Service Industries Journal 30 (6), 911-928

43. International journal of research in computer application and management Volume no. 32013 issue no. 03 march (Hubona and Kennick (1996)

44. Iqbal, U., Rizwan, M., Zafar, A., Khan, M. H., Usman, M. \& Iqbal, D. (2013) Determinants Uncovering the Brand Loyalty: A Signaling effect of Price on Quality Perception. Journal of Basic and Applied Scientific Research, 3(11), 212-221

45. Jacoby J, Chestnut, R.W and Fisher W.A 1978 A Behavioral Process Approach to Information Acquisition in Nondurable Purchasing; Jololirnitl oflMnrketi igiZeseal.clz 15.4 532-544

46. Jalab 1952 the Effect of Brand Trust and Perceived Value in Building Brand Loyalty International Research Journal of Finance and Economics ISSN 1450-2887 Issue 85 (2012)

47. Jones, M. A., \& Suh, J. (2000) Transaction-specific satisfaction and overall satisfaction: An empirical analysis Journal of Services Marketing, 14(2), 147-159 Jo“reskog, K. G., \& So“rbom, D. (1996) LISREL 8 user's reference guide Chicago: Scientific Software International

48. Joseph, J. \& Bharadhwaj, S. (2009) the moderating effect of loyalty on the relationship of sales promotions and brand equity Advances in Consumer Research 8, pp. 263-264

49. Kandampully, J. \& Suhartanto, D. (2000) "Customer Loyalty in the Hotel Industry: The Role of Customer Satisfaction and Image," International Journal of Contem- porary Hospitality Management, 12(6), 346-351.

50. Kartono, B. \& Rao, V.R. (2005) Linking consumer-based brand equity to market performance: An integrated approach to brand equity management (Working Paper Series 30-06) New York: Cornell University

51. Keller, K.L. (1993), "Conceptualizing, measuring, and managing customer-based brand equity", Journal of Marketing, Vol. 57 No. 1, pp. 1-22

52. Keller, K.L. (1998), Strategic Brand Management: Building, Measuring and Managing Brand Equity, Prentice Hall, Englewood Cliffs, NJ

53. Keller, K.L. (2003b) Strategic brand management: building, measuring, and managing brand equity, Second Edition, Upper Saddle River, Prentice Hall, NY

54. Kiesler, C.A., (1971), Commitment in Theories of Cognitive Consistency: a Sourcebook, Abelson, R.P., Chicago: Ran Mc Nally, pp. 448-455 


\section{Macrothink}

Journal of Sociological Research

ISSN 1948-5468

2014, Vol. 5, No. 1

55. Kim KY, Kim Ka, Kim D, Kim J, kang S (2008) Brand equity in hospital marketing Journal of business research 61, 75-82

56. Kim, J., Jon D. M. \& Joffre S. (2008) Antecedents of true brand loyalty. Journal of Advertising 37(2), pp. 99-117.

57. Knox, S. \& Walker, D. (2001) Measuring and managing brand loyalty Journal of Strategic Marketing 9, pp. 111-128

58. Kotler P., Armstrong G., Saunders J. Wong V. (2002) Principle of Marketing, 3rd edition, Pretence Hall \$Europe

59. Kotler, 1997Marketing Management, ninth Edition, Prentice Hall Inc., USA.

60. Krishnamurthi, L., Mazumdar, L.T. and Raj, S.P. (1992), "Asymmetric response to price in consumer brand choice and purchase quantity decisions", Journal of Consumer Research, Vol. 19 No. 3, pp. 387-400

61. Kumar V., (2005), "Balancing Acquisition and Retention Resources to Maximize Customer Profitability", Journal of Marketing, Vol.69, p.63-79

62. LaBarbera, P.A. and Mazursky, D. (1983), "A longitudinal assessment of consumer satisfaction/dissatisfaction", Journal of Marketing Research, Vol. 20, pp. 393-404

63. Larzelere, Robert and Huston, Ted L. (August 1980) "The Dyadic Trust Scale: Toward Understanding Interpersonal Trust in Close Relationships", Journal of Marriage and the Family, pp.595-604.

64. Lee J, Back K (2008) Attendee-based brand equity Tour Manage, 29(2): 331-344

65. Lewis, J.D. and A. Weigert (1985), trust as a Social Reality Social Forces, 63, 967-985.

66. Liu, Y. (2007) "The long term impact of loyalty programs on consumer purchase behavior and loyalty", Journal of Marketing, Vol.71, No.4, pp.19-35

67. Lym et al, 2010 IMPACT OF BRAND SWITCHING, BRAND CREDIBILITY, CUSTOMER SATISFACTION AND SERVICE QUALITY ON BRAND LOYALTY European Journal of Developing Country Studies, Vol.4 2007 ISSN (paper) 2668-3385 ISSN (online) 2668-3687

68. Maathuis, O., Rodenburg, J. and Sikkel, D. (2004), “Credibility, emotion, or reason?” Corporate Marketing Theory and Practice, Vol. 7 No. 2, pp. 136-46

69. Mathew, V., Thomas, S. \& Khader, N. (2011) the impact of satisfaction relationship quality and affective commitment on loyalty intentions In Jawahar, David P. (Eds.), towards managerial excellence challenges and choices Pp.197-209 New Delhi, India: Macmillan

70. Matzler, K., Krauter, S. G., \& Bidmon, S. (2008). Risk aversion and brand loyalty: The mediating role of brand trust and brand affect. Journal of Product \& Brand 
Management, 17(3), 154-162.

71. McConnell J. D. (1968), “The Development of Brand Loyalty: An Empirical Study", Journal of Marketing Research, Vol. 5, pp. 13-19.

72. Moorman, C., Zaltman, G. \& Deshpande, R. (1992) "Relationships between providers and users of marketing research, the dynamics of trust within and between organizations", Journal of Marketing Research, Vol.29, No.3, pp.314-329.125 International Research Journal of Finance

73. Morgan, R. M. \& Hunt, S. D. (1994) "The commitment-trust theory of relationship marketing", Journal of Marketing, Vol.58, No.3, pp.20-38. Strategic Management Journal, Vol.15 (Special issue), pp.175-190

74. Mowen, J. C., \& Minor, M. (2001) Consumer behavior: A framework (2nd Ed) Upper Saddle River, New Jersey: Prentice-Hall

75. Najem 1952 the Effect of Brand Trust and Perceived Value in Building Brand Loyality International Research Journal of Finance and Economics ISSN 1450-2887 Issue 85 (2012)

76. Olive, R.L. (1999), “Whence consumer loyalty?” Journal of Marketing, Vol. 63 No. 4, pp. 33-44

77. Oliver, R. (1980) A cognitive model of the antecedents and consequences of satisfaction decisions Journal of Marketing Research, 17, 460-469.

78. Oliver, Richard L. (1993), "Cognitive, Affective, and Attribute Bases of the Satisfaction Response," Journal of Consumer Research, 20 (3), 418-30. Westbrook, Robert A. and Richard L

79. Oliver, Richard L. 1977. "Effect of Expectation and Disconfirmation on Post exposure Product Evaluations: An Alternative Interpretation” Journal of Applied Psychology 62 (August): 480-486

80. Olsen, S. O. (2002) "Comparative Evaluation and the Relationship between Quality, Satisfaction, and Repurchase Loyalty", Journal of the Academy of Marketing Science, Vol.30, No.3, pp.240-49

81. Parasuraman A, Grewal D (2000). The impact of technology on the quality-value-loyalty chain: a research agenda J. Acad. Mar Sci., 28(1): 168-174

82. Pritchard MP, Havitz ME, Howard DR (1999). Analyzing commitment loyalty link in service contexts J. Acad. Mar. Sci., 27(3): 333-348 ， E.W

83. Ragunathan, in addition, Irwin, J.R. (2001), "Walking the hedonic product treadmill: default contrast and mood-based assimilation in judgments of predicted happiness with a target product", Journal of Consumer Research, Vol. 28 No. 3, pp. 355-68.

84. Rangaswamy, A., Burke, R. \& Oliva, T.A. (1993) Brand equity and the extendibility 


\section{Macrothink}

of brand names International Journal of Research in Marketing 10(1), pp. 61-75

85. Reichheld, F. \& Schefter, P. (2000) "E- Loyalty, "Harvard Business Review, 78 (4): 105- 114 Relationships Journal of Personality and Social Psychology, 49 (1), 95-112.

86. Rempel, John K., John G. Holmes, and Mark P. Zanna (1985), trust in Close

87. Rodriguez, K. P. (2008) “Apparel Brand Endorsers and their Effects on Purchase Intentions: A Study of Philippine Consumers", Philippine Management Review, 15, pp. 83-99.

88. Rizwan, M., Akbar, I., Muqtadir, A., Shafique, U., Zia, H., Naseer, W. and Amin, S. A. (2013) Impact of Brand Switching, Brand Credibility, Customer Satisfaction and Service Quality on Brand Loyalty, IOSR Journal of Business and Management, Vol. 1 (special issue), 12-20

89. Rotter, Julian B. (1980), interpersonal Trust, Trustworthiness, and Gullibility American Psychologist, 35 (1), 1-7

90. Russell-Bennett R, McColl-Kennedy JR, Coote LV (2007) Involvement, satisfaction and brand loyalty in a small business services setting J. Bus. Res., 60(12): 1253-1260

91. Serge Dimitriadis, le Management de la Marque, organiza d'organizations, 2000 (Serge Dimitriadis, the Brand Management, organiza of organisms, 2000) International Research Journal of Finance and Economics - Issue 85 (2012) 126

92. Shin, H., Lee, S., \& Kim, H. (2009) “The Relationship between Non-Monetary Impacts and Monetary Assistance for Sporting Event” Presented at the 2009 North American Society for Sport Management (NASSM) Conference (Columbia, South Carolina, May 27-30, 2009).

93. Shugan, S. (1980), “The cost of thinking”, Journal of Consumer Research, Vol. 7, pp. 99-111

94. Sternthal, B. and Craig, C.S. (1982), Consumer Behavior: An Information Processing Perspective, Prentice-Hall, Englewood Cliffs, NJ

95. Swait, J. and Erdem, T. (2007), "Brand effects on choice and choice set formation under uncertainty”, Marketing Science, Vol. 26 No. 5, pp. 679-97

96. Tawfiq, O.A.R. (2007) Customer service, the status of professional experience of management, Cairo

97. Tse D, Wilton PC (1988) Models of consumer satisfaction formation: an extension J. Mar. Res., 25: 204-212

98. Vargo SL, Lusch RF (2004). The four service marketing myths: remnants of a goods-based, manufacturing model. J. Ser. Res., 6(4): 324-335.

99. Veloutsou Gilbert, G. R Moutinho, L. A., \& Goode, M. M. H. (2005) Measuring transaction-specific satisfaction in services: Are the measures transferable across 
cultures? European Journal of Marketing, 39(5/6), 606-628

100. Verhoef, P. C. (2003). Understanding the effect of customer relationship management efforts on customer retention and customer share development. Journal of Marketing 67 (October), pp. 30-45.

101. Wilton, P. C. (1988). Models of consumer satisfaction formation: An extension Journal of Marketing Research, 25(2), 204-212

102. Wood, L. (2002). Brands and brand equity: definition and management. Management Decision (38) 9:226-669

103. Wood, L. (2004), "Dimensions of brand purchasing behavior: consumers in the 18-24 age group", Journal of Consumer Behavior, Vol. 4 No. 1, pp. 9-24

104. Yi Youjae. 1990. “A Critical Review of Consumer Satisfaction.” In Re-view of Marketing Valerie A. Zeithaml Chicago: American Marketing Association, 68-123

105. Yoo, B. \& Donthu, N (2001) Developing and validating multidimensional consumer-based brand equity scale. Journal of Business Research 52(1), pp

106. Yoo, B., Donthu, N. and Lee, S. (2000), “An examination of selected marketing mix elements and brand equity", Journal of the Academy of Marketing Science, Vol. 28 No. 2, pp. 195-211

107. Zeithaml, V.A. (1988) "Consumer perceptions of price, quality, and value: A means-end model and synthesis of evidence", Journal of Marketing, Vol.52, No.3, pp. $2-22$.

108. Zikmund, G. W. (1997). Business research methods $\left(5^{\text {th }}\right.$ Ed) Florida: The Dryden Press. 